\title{
WADAH KREASI DAN REKREASI DI CENGKARENG TIMUR
}

\author{
Michael Fernandez Karyadi ${ }^{1}$, Fermanto Lianto $^{2)}$ \\ 1)Program Studi S1 Arsitektur, Fakultas Teknik, Universitas Tarumanagara, michaelfernandez452@gmail.com \\ 2)Program Studi S1 Arsitektur, Fakultas Teknik, Universitas Tarumanagara, fermantol@ft.untar.ac.id
}

\begin{abstract}
Abstrak
Di era modern ini, perkembangan industri dan niaga sangatlah pesat, menghasilkan banyak pabrik-pabrik and toko-toko dari yang berskala besar hingga mikro. Salah satu contoh wilayah yang berkembang dalam bidang ini adalah Cengkareng Timur yang terletak di Jakarta. Wilayah ini memiliki aktivitas yang sangat padat, mulai dari perdagangan, produksi, mulai dari usaha besar, menengah hingga usaha mikro. Dilain sisi, wilayah ini juga padat akan pemukiman menengah dan kebawah, terlihat dari padatnya bangunan dan penduduk. Sebagai akibat dari tingginya fokus dan aktivitas masyarakat di bidang industri dan niaga, wilayah ini kekurangan fasilitas sosial dan terkategori sebagai wilayah dengan Indeks Kerawanan Lingkungan dan Kesehatan (IKLK) tertinggi se DKI-Jakarta. Melalui observasi, pengumpulan data, dan wawancara, data-data dan kebutuhan serta aspirasi masyarakat dikumpulkan dan dikelola menurut teori third place dan nest concept, sehingga menghasilkan Wadah Kreasi dan Rekreasi di Cengkareng Timur yang didesain sepenuhnya berdasarkan kebutuhan masyarakat Cengkareng Timur untuk bercengkrama, bersantai, melepas penat, dan mengisi waktu luang, namun tetap produktif. Third place ini mengajak masyarakat untuk turut aktif dalam mengolah sampah terutama sampah kertas. Melalui aktivitas ini seseorang/masyarakat dapat meningkatkan kualitas hidup dan potensi dirinya, secara sosial, maupun keterampilan. Bangunan ini sendiri dibuat dari berbagai macam sampah seperti botol bekas, kertas sisa, kayu bekas dan lain-lain yang diolah Kembali dan dibentuk menjadi sebuah bangunan yang fungsional dan nyaman, dengan kata lain bangunan ini adalah 'mahakarya' yang terbuat dari sampah.
\end{abstract}

Kata kunci: arsitektur; cengkareng timur; fasilitas; kerajinan tangan kertas; tempat ketiga

\begin{abstract}
In todays modern era, the development of industry and commerce is extremely potent, producing lots of factories, and shops ranging from large scale to micro scale. An example of the district that is known to develop in this field is East Cengkareng located in west of Jakarta.This district, this area is packed with activities, from commerce and production, ranging from big to medium to micro business. On the other hand, this district also packed by middle rank to lower rank residential, proven from the concentrated small housing despite its high-density population. The consequences of highly concentrated activities in commerce and industry is a less developed facilities and categorized as a district with the highest Environmental and health problem in Jakarta. Through observation, data collection, and interviews, the advice, and aspirations of the residents are collected and reorganized based on third place theory and nest concept producing Creation and Re-Creation Building in East Cengkareng as a building designed entirely based on the needs of the residents around to talk, relax, relieve stress, and yet remain productive. This third place encourage people to recycle and remake trash actively. Through this activity, people can increase their life's qualities and develop their potential, socially or skillfully. This building itself is made from many kinds of trashes such as waste plastic bottles, paper scraps, wood pieces, and others that are recycled and remade into a functional and comfortable building; in other words, this building is a 'masterpiece' on its own built with trashes.
\end{abstract}

Keywords: architecture; east cengkareng; facilities; papercraft, third place 


\section{PENDAHULUAN}

\section{Latar Belakang}

Indonesia merupakan negara yang masih dalam tahap perkembangan, oleh karena itu pembangunan sangat diutamakan diberbagai sektor, baik dari segi infrastruktur, ekonomi, taraf hidup, kesehatan, dan lain-lain dengan tujuan untuk meningkatkan kesejahteraan sosial. (Arsyad, 2004). Salah satu sektor yang difokuskan pembangunannya dan banyak berkontribusi dalam perkembangan Kota Jakarta adalah sektor niaga dan industri. Banyak wilayah di Jakarta mengedepankan kedua sektor ini, dengan harapan bahwa kehidupan masyarakat akan meningkat secara ekonomi, namun dalam pesatnya perkembangan di bidang ini, banyak bagian penting dalam kehidupan masyarakat terabaikan seperti Kesehatan, kehidupan sosial and kebersihan lingkungan.

Cengkareng Timur merupakan sebuah kelurahan yang teletak di Jakarta Barat. Wilayah ini dikenal sebagai wilayah niaga dan industri karena di wilayah ini terdapat berbagai macam pertokoan kecil, mulai dari bengkel, warung, toko sembako, pulsa, pakaian, pabrik, dan lainlain. Selain padat akan aktivitas niaga dan industri, wilayah ini juga padat akan permukiman. Jumlah penduduk di kelurahan ini mencapai sekitar 97.677 jiwa dengan mayoritasnya terkategori sebagai masyarakat menengah kebawah. Padatnya aktivitas industri dan pemukiman ini menyebabkan wilayah ini menjadi tidak terkelola dengan baik, mulai dari kurangnya fasilitas bagi warga sekitar, kesenjangan sosial, hingga lingkungan yang sangat buruk. Kelurahan Cengkareng Timur menempati peringkat pertama dalam Indeks Kerawanan Lingkungan dan Kesehatan (IKLK) tertinggi se DKI-Jakarta (BPS, 2019).

Proyek ini mengangkat tema secara garis besar yaitu reduce, reuse \& recycle yang diolah sedemikian rupa sehingga menjadi bangunan yang menjadi third place bagi warga di Cengkareng Timur. Warga memerlukan tempat untuk menyalurkan minat dan bakatnya, bersantai dan bercengkrama, namun tetap bisa menghasilkan pendapatan tambahan. Secara lingkungan, Kelurahan Cengkareng Timur perlu dididik agar lebih mengerti tentang sampah, potensi dan manfaatnya secara ekonomi dan kesehatan, sehingga secara perlahan melalui third place ini lingkungan akan menjadi lebih bersih dan secara tidak langsung kualitas hidup masyarakat sekitar dapat meningkat.

\section{Rumusan Permasalahan}

Terdapat dua rumusan permasalahan yang dijawab melalui penelitian ini yang kemudian digunakan sebagai landasan untuk perancangan Wadah Kreasi dan Rekreasi di Cengkareng Timur, yakni:

a. Bagaimana arsitektur dapat menyediakan third place yang menarik perhatian warga di Cengkareng Timur sekitar serta memberi kenyamanan bagi penggunanya?

b. Bagaimana program arsitektur mampu untuk membantu meningkatkan kualitas lingkungan dan hidup masyarakat di sekitar Cengkareng Timur, namun tetap menjadi fasilitas bagi masyarakat untuk bersantai dan bersosialisasi?

\section{Tujuan}

Studi ini diharapkan mampu menjawab kedua permasalahan diatas dan memenuhi tujuan dari penelitian ini, yaitu menciptakan third place yang mampu memberikan kenyamann secara fungsional dan visual serta mampu untuk meningkatkan kualitas lingkungan dan hidup masyarakat dari segi ekonomi, kesehatan, dan sosial. 


\section{KAJIAN TEORI}

\section{Third Place}

Third place adalah sebuah wadah yang bertujuan untuk relaksasi dan sosialisasi bagi penggunanya. Third place merupakan tempat tujuan ketiga bagi masyarakat selain rumah dan tempat kerja. Terdapat 8 kriteria suatu tempat dapat disebut sebagai third place (Oldenburg, 1989), yaitu:

a. Accessibility \& Accommodation

Sebuah third place harus dapat diakses dengan gampang oleh penggunanya. Sebuah third place menyediakan apa yang diinginkan dan dibutuhkan oleh penggunanya sehingga penggunanya merasa bahwa kebutuhannya terpenuhi.

b. Neutral ground

Tempat ini merupakan tempat dimana orang tidak memerlukan kriteria dan keterikatan apapun agar bisa masuk kesana. Semua orang dapat pergi dan pulang sesukanya kecuali yang bekerja disana.

c. Leveler (a leveling place)

Didalam tempat ini, semua orang memiliki status sosial yang sama, sehingga memungkinkan terjadinya interaksi secara merata dan tidak ada diskriminasi.

d. Regulars

Third place memiliki ciri yang "welcoming" dimana semua orang dapat masuk dan bahkan diundang untuk masuk dan bersosialisasi. Third place bersifat informal dan biasanya memiliki pengunjung tetap atau dengan kata lain orang-orang yang sering datang dan beraktivitas disini.

e. Conversation is the main activity

"playful \& happy conversation" adalah fokus dari third place. Aktivitas-aktivitas yang dilakukan memungkinkan terjadinya interaksi-interaksi yang membahagiakan.

f. Playful Mood

Desain dari third place ditujukan agar "playful", mulai dari aktivitas-aktivitasnya, desain ruangnya, dan lain-lain. Semua orang yang berada disana merasa bahagia dan menikmati waktu luangnya.

g. A Low Profile

Third place secara bangunan tidak menonjol dan terlihat biasa saja. Desain bangunan third place lebih ditujukan untuk membaur dengan lingkungan sekitar, menarik orang agar tidak minder untuk masuk, dan mengundang semua orang untuk masuk dan beraktivitas didalam.

h. A home away from home

Di dalam third place, orang diharapkan agar merasa seperti ada dirumah kedua dan menjadi tempat dimana orang akan merasakan "spiritual regeneration", dimana orang menjadi lebih semangat, melepas rasa lelah secara fisik maupun mental dan merasakan rasa "belongings".

\section{Meregulasi Perilaku Pengguna Melalui Desain Arsitektural}

Sebuah konsep baru sedang muncul yaitu bahwa arsitektur bekerja sebagai pengatur regulasi (Shah \& Kesan, 2007). Hal ini menandakan bahwa arsitektur dapat digunakan dalam hubungannya dengan sistem pengaturan, seperti hukum tertentu dan norma sosial. Sebuah bentuk (form), simbol, warna, peletakan furnitur, efek cahaya, material, temperatur, dan lainlainnya dapat mempengaruhi/meregulasi seseorang.

Desain yang dibuat secara tidak langsung akan mempengaruhi interaksi sosial yang informal yang dimana ternyata arsitektur itu memanipulasi konsepsi kita terhadap personal space dan territoriality yang berakhir pada kemampuan sebuah desain untuk mendominasi dan mendisiplin seseorang. Adapun prinsip-prinsip terkait hal tersebut adalah sebagai berikut: 
a. Interaksi Sosial

Desain dari suatu bentuk atau ruang dapat diatur untuk mendukung atau meminimalisir interaksi sosial. Seperti hallways/jalur Lorong cenderung membuat orang tidak berkomunikasi sedangkan ruang yang melingkar cenderung membuat orang berinteraksi. Selain jalur melingkar, adanya bukaan-bukaan dan minimnya pembatas juga memicu terjadinya interaksi (Osmond, 1957). Triangulation adalah sebuah proses dimana terdapat stimulus eksternal yang menyediakan hubungan antar orang dan mendorong sesama orang asing untuk berbicara dengan satu sama lain seperti seolah mereka mengenal satu sama lain (Whyte, 1980). Contoh dari triangulation dapat dilihat dalam gambar dibawah ini (Gambar 1).

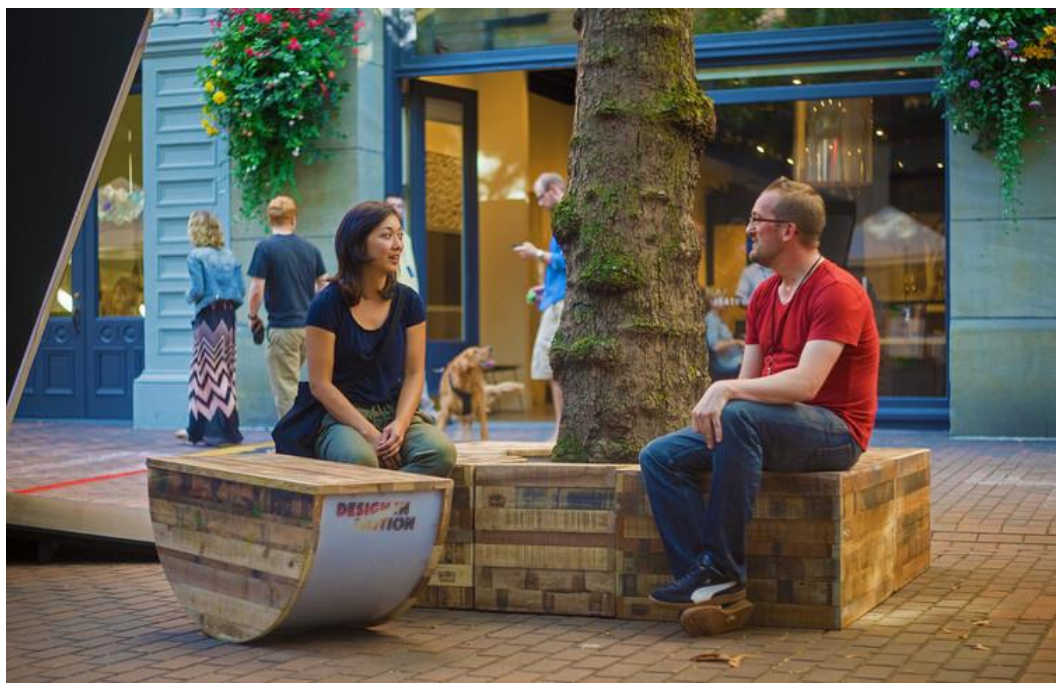

Gambar 1. Pop-up! Street Furniture by LMN Architects

Sumber: https://archello.com/project/pop-up-street-furniture, diunduh 13 Maret 2020

Proyek yang dibuat di tengah Kota Seattle ketika festival desain Seattle ini mampu bertransformasi menjadi berbagai macam bentuk melalui 8 modulasi yang bisa digabungkan/dipisahkan dan disusun ulang. Tempat ini menjadi pusat sementara untuk berbicara, bermain dan berinteraksi.

b. Personal Space \& Territoriality

Personal space adalah sebuah gelembung yang tidak terlihat yang mengelilingi suatu makhluk hidup. Personal space ini bersifat dinamis dan dapat berubah apabila area ini dimasuki oleh orang lain (Halim, 2005). Lingkungan sekitar dapat mempengaruhi persepsi kita terhadap sebuah ruang dan wilayah. Apakah ruang tersebut lebih privat atau lebih publik, dan sebagainya. Privasi terkadang didefinisikan sebagai sebuah proses "pengasingan", dimana kita terkadang ingin terpisah dan dilain waktu ingin melakukan kontak dengan orang lain (Altman, 1975).

c. Ruang dapat mendisiplinkan

Desain sebuah bangunan dapat mempengaruhi interaksi sosial juga dengan mendominasi dan mengontrol orang (Katyal, 2002). Sebagai contoh, di sekolah bagaimana kelas dibagibagi dan kursi antar murid diatur agar dapat dipantau dengan mudah sehingga hal ini mempersulit interaksi, namun ketika kelas tidak dibagi-bagi dan memang ditujukan untuk diberi fleksibilitas dalam pengajaran dan aktivitas, maka interaksi akan menjadi lebih gampang (Gambar 2). Bangunan dapat mempengaruhi kebebasan kita, dari lokasi, alur pergerakan, jalur visual, area yang pertemuannya telah diatur, dan area yang dibuat sedikit pertemuan. 


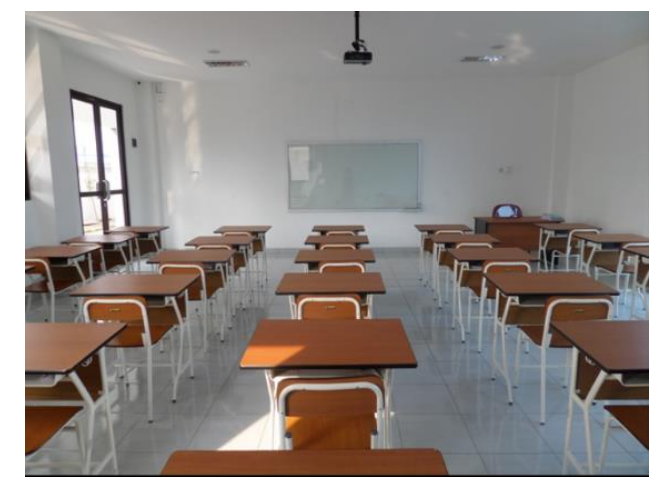

Gambar 2. Ruang Kelas yang Diatur Agar Mudah Dipantau

Sumber: www.google.com, diunduh 13 Maret 2020

\section{Kerajinan Tangan Kertas dan Dampaknya Secara Psikologis}

Aktualisasi diri merupakan salah satu kebutuhan dasar dalam hidup dan setiap orang mempunyai naluri akan keindahan, pada beberapa orang, kebutuhan keindahan ini begitu mendalam dan berhubungan dengan gambaran diri seseorang, bahkan didalam beberapa penelitian menunjukkan bahwa keindahan membuat seseorang lebih sehat (Goble, 1970). Salah satu metode untuk aktualisasi diri yang paling mudah adalah dengan melakukan kerajinan tangan kertas. Membuat kerajinan tangan kertas adalah sebuah kegiatan yang berulang dengan tingkat keterampilan yang selalu dapat ditingkatkan yang disebut dengan flow atau aliran. Hal ini memungkinkan seseorang untuk memasuki sebuah keadaan yang seimbang antara keterampilan dan tantangan yang kemudian menghasilkan pengalaman yang optimal. Selama berada dalam keadaan yang mengalir itu, seseorang biasanya akan merasakan kesenangan yang mendalam, kreativitas, dan keterlibatan secara total dengan kehidupan. Suatu kondisi flow dalam otak itulah yang membantu kita untuk melepaskan diri dari tekanan kehidupan modern (Csikszentmihalyi, 1990). Sebagai contoh ketika dilakukan pelatihan kertas di Bentara Budaya oleh Agus Winarto, banyak yang merasa bahwa kerajinan ini seperti layaknya sebuah terapi karena melatih kesabaran dan menyenangkan. "Kerajinan kertas yang saya adakan selalu membuat orang senang karena saya tidak melihat hasil bagus atau gimana, yang penting menyenangkan dalam prosesnya," tutur Agus (Ayudiana, 2019).

\section{METODE}

Metode yang digunakan dalam pengumpulan data adalah observasi lapangan, kajian Pustaka, wawancara dan studi Pustaka, sedangkan dalam mengolah data dan perancangan proyek Wadah Kreasi dan Rekreasi di Cengkareng Timur adalah melalui metode nest concept dari RAW Architecture yang mengutamakan program, struktur, material dan detail. Hasil dari penerapan konsep ini adalah sebuah bentuk yang didasari oleh fungsi arsitektural secara langsung (Form follow function) yang secara tidak langsung juga membantu dalam pembentukan bangunan secara structural maupun konseptual, karena bangunan banyak menggunakan sampah bekas sebagai material, dan detailnya.

Langkah-langkah dalam pengumpulan dan pengolahan data dalam penelitian ini adalah sebagai berikut:

a. Mengkaji tentang teori third place dari buku the great good place (Oldenburg, 1989), teori tentang how architecture regulates (Shah \& Kesan, 2007), teori Function as the Basis of psychiatric Ward Design (Osmond, 1957), dan Methodgram: Methodology Grammar (Sjarief \& Hidayat, 2019).

b. Mengidentifikasi masalah dan kebutuhan dari masyarakat di Kelurahan Cengkareng Timur. Proses pengumpulan data dilakukan dengan cara melakukan pengamatan langsung di lapangan dan wawancara terkait warga yang berdomisili/sering beraktivitas di wilayah ini. Setelah observasi dan wawancara dilakukan maka tahap selanjutnya adalah mencari data- 
data pendukung yang diambil dari Badan Pusat Statistik (BPS) dan media-media informasi lainnya terkait Kelurahan Cengkareng Timur.

c. Setelah ditemukan permasalahan, citra, dan potensi dari kawasan telah didapatkan, Langkah selanjutnya adalah menggabungkan data yang didapat dari lapangan dan internet sehingga menghasilkan sebuah usulan program yang kemudian diperkuat dengan teoriteori pendukungnya. Setelah itu, usulan program disesuaikan dengan komposisi ruang, elemen arsitektural berdasarkan akumulasi hasil kajian-kajian yang telah dilakukan terhadap kawasan Cengkareng Timur.

\section{DISKUSI DAN HASIL}

Secara tata ruang, Kawasan Cengakreng Timur memiliki urban fabric yang tidak teratur, ada sebagian yang tertata, namun ada juga sebagian yang organik. Secara makro, bentuk Kelurahan ini menyerupai bentuk $\mathrm{L}$ dan didominasi oleh aktivitas perniagaan dan industri, mulai dari pabrik manufaktur mesin, pabrik pengemasan, tekstil, pertokoan dan ruko, hingga warung-warung kecil, bengkel-bengkel kecil, dan pasar. Dilain sisi, Kelurahan Cengkareng Timur ini juga padat akan pemukiman, jumlah penduduk di kelurahan ini mencapai sekitar 97.677 jiwa yang dimana mayoritas berprofesi sebagai karyawan swasta, pelajar/mahasiswa, dan mengurus rumah tangga. Tapak dipilih ditengah-tengah cengkareng timur (ditandai dengan huruf $A$ di gambar 3 ), tepat berbatasan antara pemukiman menengah kebawah dan kumuh dengan area yang banyak terdapat ruko dan pertokoan. Lokasi tapak ini memudahkan bagi warga dari segala sisi untuk mencapai third place dapat dilihat melalui gambar dibawah ini.

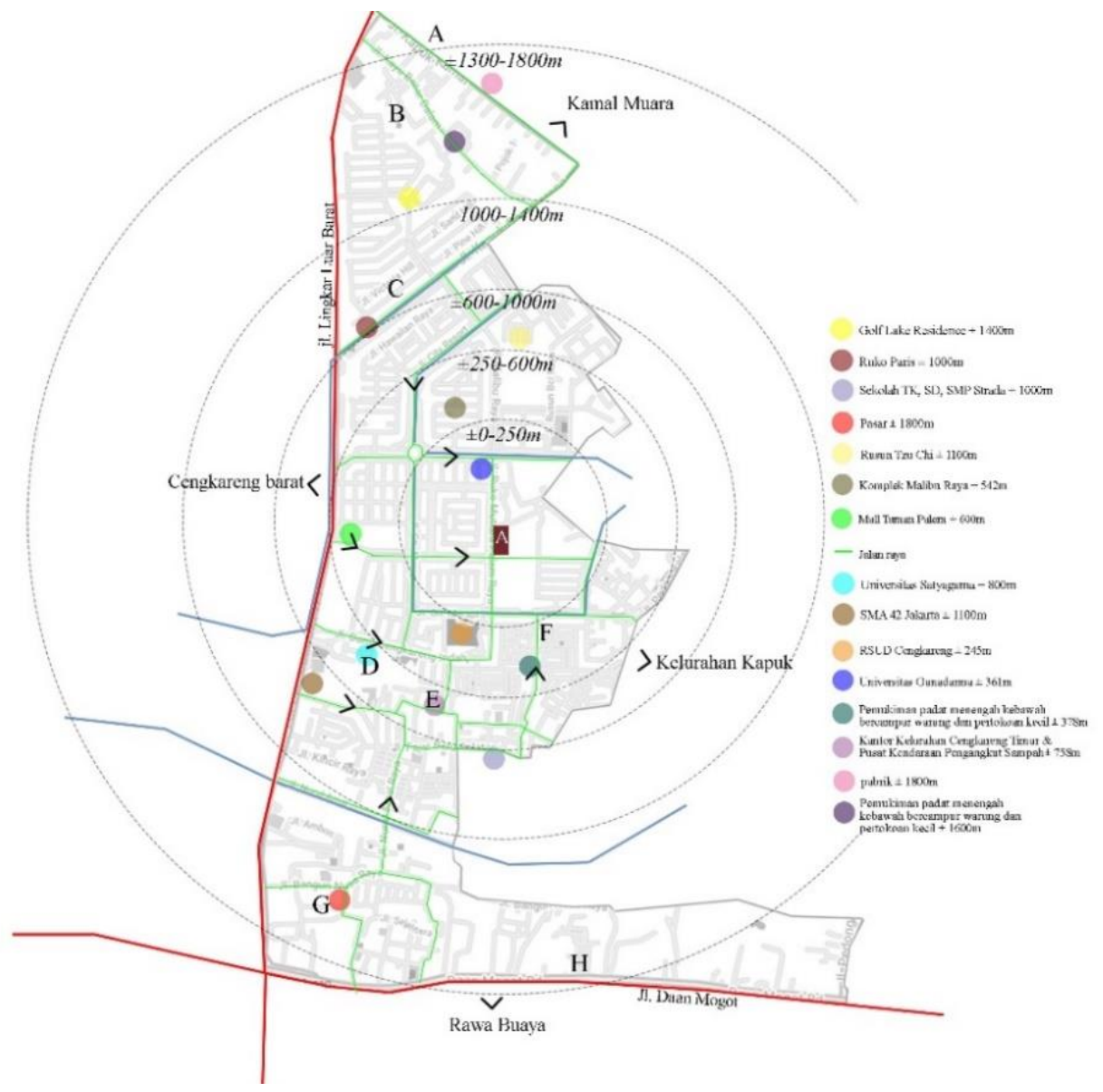

Gambar 3. Kawasan Cengkareng Timur

Sumber: www.snazzymaps.com, dielaborasi oleh penulis 2020, diunduh 13 Maret 2020 
Tapak yang terletak di Jl. Ruko Mutiara Palem Raya dengan luas lahan $2520 \mathrm{~m}^{2}$ (Gambar 4) ini memiliki keunikan yaitu ketika pagi hingga siang terdapat sedikit pedagang kaki lima (PKL) yang berjualan, namun ketika sore menjelang malam, intensitas orang berjualan meningkat. Komoditi jualan sangatlah bervariatif, mulai dari pakaian, perhiasan, hewan, mainan, aksesoris, makanan, dan lain-lain. Secara natural, daerah ini memang telah menjadi daya tarik tersendiri dan banyak warga yang mengunjungi pasar malam ini. Daerah yang padat akan aktivitas Ketika sore dan malam hari ditandai dengan lingkaran merah (lih. Gambar 4).

Bangunan di desain untuk merespon terhadap tapak baik dari segi geologis maupun secara kondisi sosial lingkungan. Karena suasana sore dan malam yang ramai dan ribut, maka posisi bangunan diletakkan sedikit ke belakang dan tanaman digunakan untuk mereduksi tingkat keributan, selain sebagai pereduksi keributan, tanaman juga berperan sebagai peneduh akses masuk. Tapak memiliki 5 akses masuk menjadi jalan pintas untuk masuk kedalam tapak dan ke jalan sebelahnya. Posisi tapak terhadap lingkungan sekitar bisa dilihat melalui gambar dibawah ini.

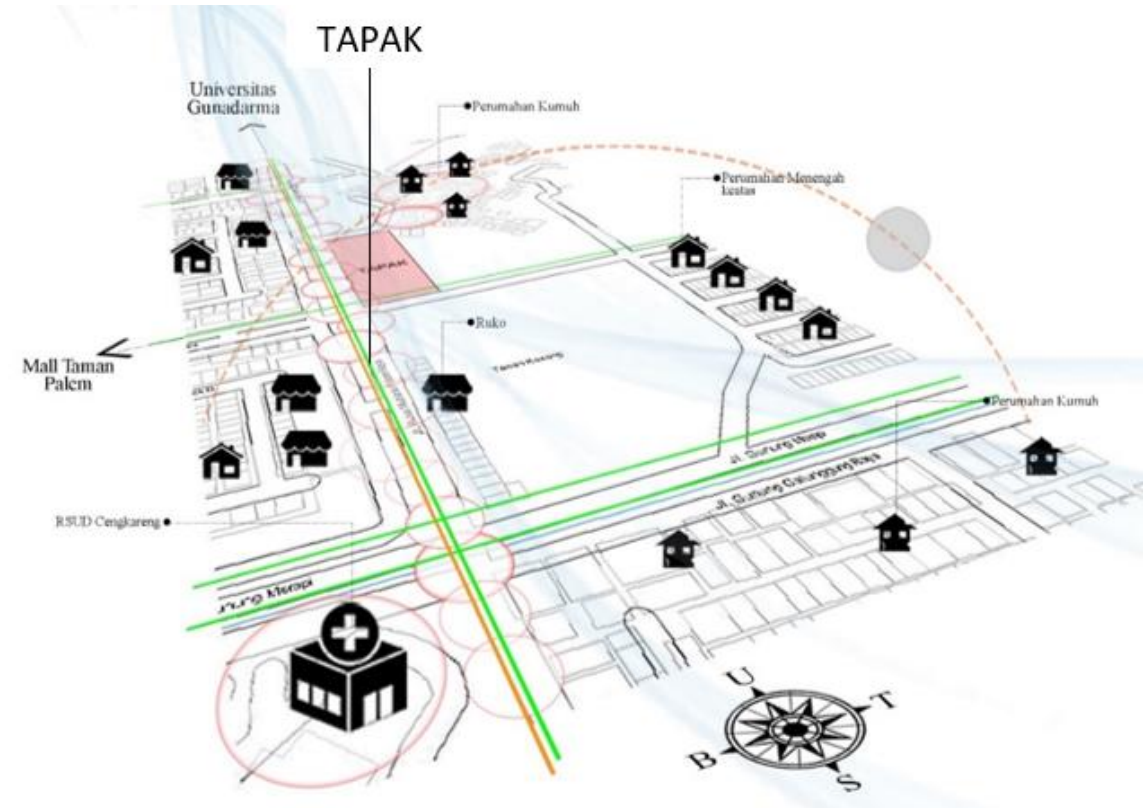

Gambar 4. Tapak dan Sekitarnya Sumber: Penulis, 2020

Desain dari bangunan mengangkat konsep kehidupan. Sampah dapat menjadi sebuah kehidupan jika dilihat dari sudut pandang yang lain. Bagi masyarakat pada umumnya maka sampah harusnya dibuang dan dijauhkan, tapi bagi Sebagian kecil orang, sampah dapat menjadi sumber bagi mereka untuk menyambung hidup. Kehidupan dapat dilihat dari dua sisi yaitu secara fisik dan secara filosofis yang dimana secara fisik, bangunan ibarat seperti sel-sel yang bekerjasama di dalam tubuh makhluk hidup untuk membentuk sebuah sistem yang membuatnya dapat berfungsi dengan baik, hal ini dapat dicapai dengan menyesuaikan desain dengan program yang diangkat tanpa melupakan bahwa antar level dan ruang memerlukan interaksi dan konektivitas. Kemudian secara filosofis, bangunan dapat menjadi tempat bagi masyarakat untuk berproses, dan meningkatkan kualitas diri dan hidupnya melalui programprogram yang disediakan.

Secara garis besar terdapat dua program utama yaitu kerajinan tangan kertas dan nonton bareng (nobar). Program utama kerajinan tangan kertas terdiri dari galeri karya dan tempat berkerajin yang didukung oleh gudang karya dan tempat penjemuran. Program ini mewadahi 
masyarakat sekitar akan kebutuhannya untuk bersantai, berelaksasi, becengkrama namun tetap bisa produktif menghasilkan sesuatu. Kerajinan kertas ini dapat dilakukan kapanpun dan tidak bersifat mengikat, selain itu, aktivitas ini juga melatih kreativitas masyarakat itu sendiri dan nantinya dapat dikembangkan dan dijual sehingga menghasilkan pendapatan tambahan. Nobar merupakan aktivitas bagi masyarakat untuk sepenuhnya bercengkrama dan bersantai, dengan atau tidak sambil berkerajin, melalui program ini, kebersamaan dapat dibina dengan lebih intens layaknya seperti 'nginap dirumah teman'. Program utama ini didukung oleh fungsifungsi lainnya seperti tempat belajar, tempat servis, taman, dan bank sampah unit (BSU). Kedua program utama ini bertindak sebagai 'penetralisir' dan warna baru bagi masyarakat di wilayah Cengkareng Timur dari kehidupan sehari-harinya yang kaku namun tetap produktif.

Kerajinan tangan kertas berperan penting dalam konsep kehidupan karena program ini berperan metode untuk aktualisasi diri. Aktualisasi diri merupakan salah satu kebutuhan dasar dalam hidup dan setiap orang mempunyai naluri akan keindahan, pada beberapa orang, kebutuhan keindahan ini begitu mendalam dan berhubungan dengan gambaran diri seseorang, bahkan didalam beberapa penelitian menunjukkan bahwa keindahan membuat seseorang lebih sehat. Semakin mudah metode untuk mengekspresikan dirinya maka semakin mudah bagi orang untuk menyalurkan naluri keindahannya. Kerajinan tangan kertas merupakan salah satu kerajinan yang lebih fleksibel dalam pembuatannya dan lebih mudah dilakukan oleh orang dari berbagai jenjang usia, mulai dari anak-anak hingga orang tua, pelaku dapat dengan lebih bebas mengolah bentuk, warna, dan konsep yang ingin dibuat, hal ini dapat secara tidak langsung membantu mereka mengekspresikan diri mereka sendiri dengan lebih baik. Selain itu, kerajinan kertas lebih gampang untuk dikombinasikan dengan material lainnya, cenderung tidak memerlukan peralatan-peralatan berat dan lebih tidak beresiko.

Secara garis besar bentuk bangunan bersifat organik dan melingkar serta minim pembatas dengan tujuan untuk memicu interaksi sosial. Bentuk bangunan terdiri dari dua bagian yang menganut bentuk yang dinamis karena kehidupan itu adalah sesuatu yang organik dan bersifat fluid. Kedua bagian bangunan ini secara denah terlihat seolah-olah seperti 2 sel yang berdempetan dan dilapis oleh selubung membran, garis berwarna merah adalah bentuk bangunan secara garis besar dan garis hijau adalah second skin yang terlihat seolah-olah seperti membran (Gambar 5).

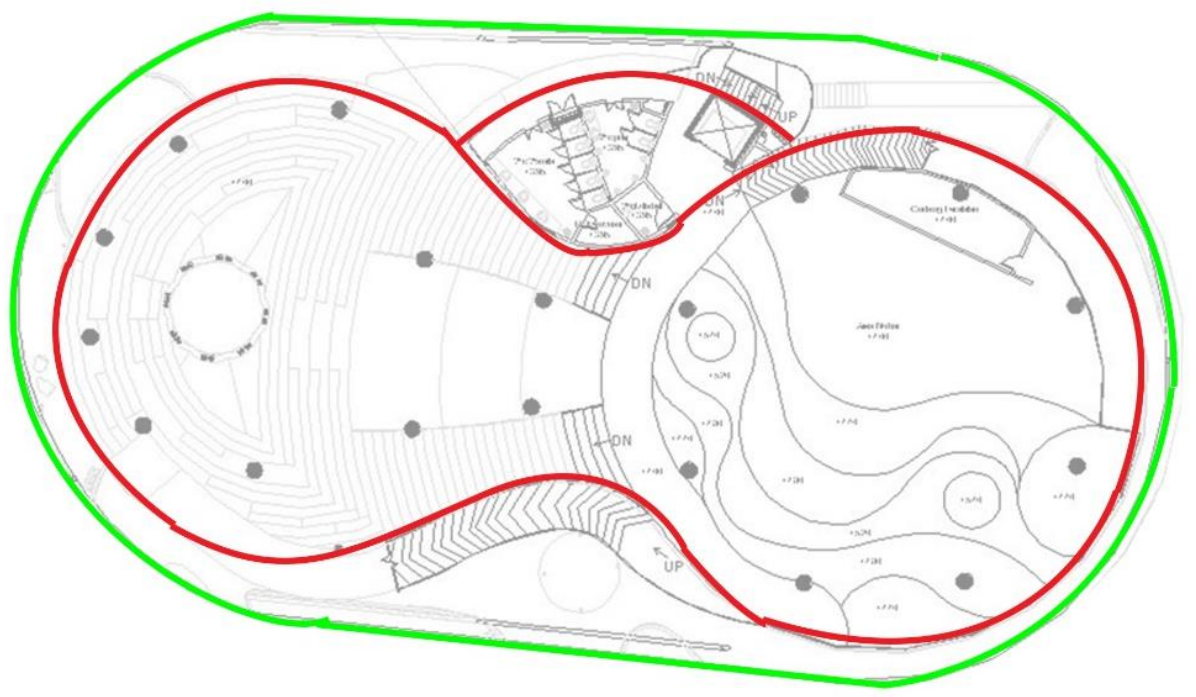

Gambar 5. Rancangan Denah Lantai Dasar Sumber: Penulis, 2020 
Secara vertikal, bangunan dibuat menjadi split level, sehingga aktivitas antar level dapat terlihat dan lebih terkoneksi antar yang satu dengan yang lainnya. Split level ini juga berfungsi sebagai upaya untuk mengalirkan udara secara bebas diseluruh bagian bangunan terlihat seperti di gambar dibawah ini (Gambar 6).

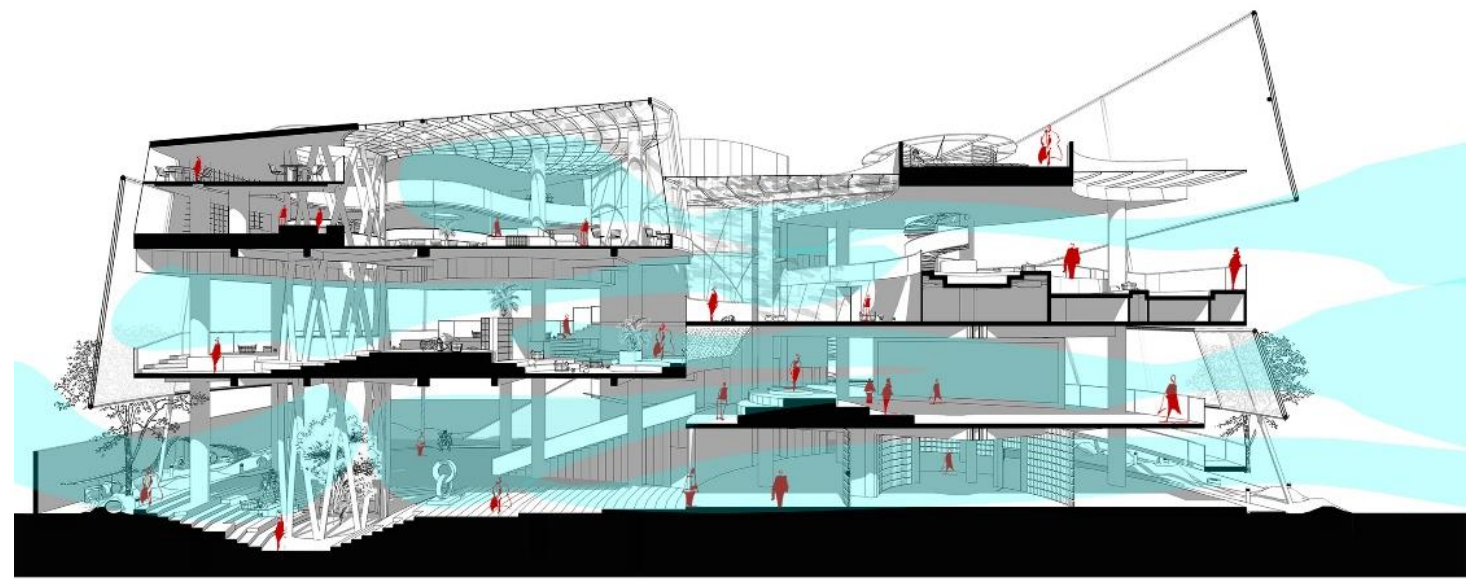

Gambar 6. Potongan Perspektif dan Skema Simulasi Pengudaraan Sumber: Penulis, 2020

Sirkulasi udara selain melalui split level, juga diatur oleh bentuk second skin yang mengangkat konsep infinity, bagian second skin terbagi menjadi dua jenis yaitu bagian yang berbentuk utuh untuk mengalirkan udara, dan ada yang berbentuk setengah utuh berfungsi untuk mengkompres dan mendinginkan udara yang lewat melalui bibir botol, peletakan posisi antar kedua jenis botol diletakkan berdasarkan arah angin datang, pada bagian yang memerlukan angin untuk diarahkan diberi botol utuh, namun di area lainnya menggunakan botol setengah utuh (Gambar 7).

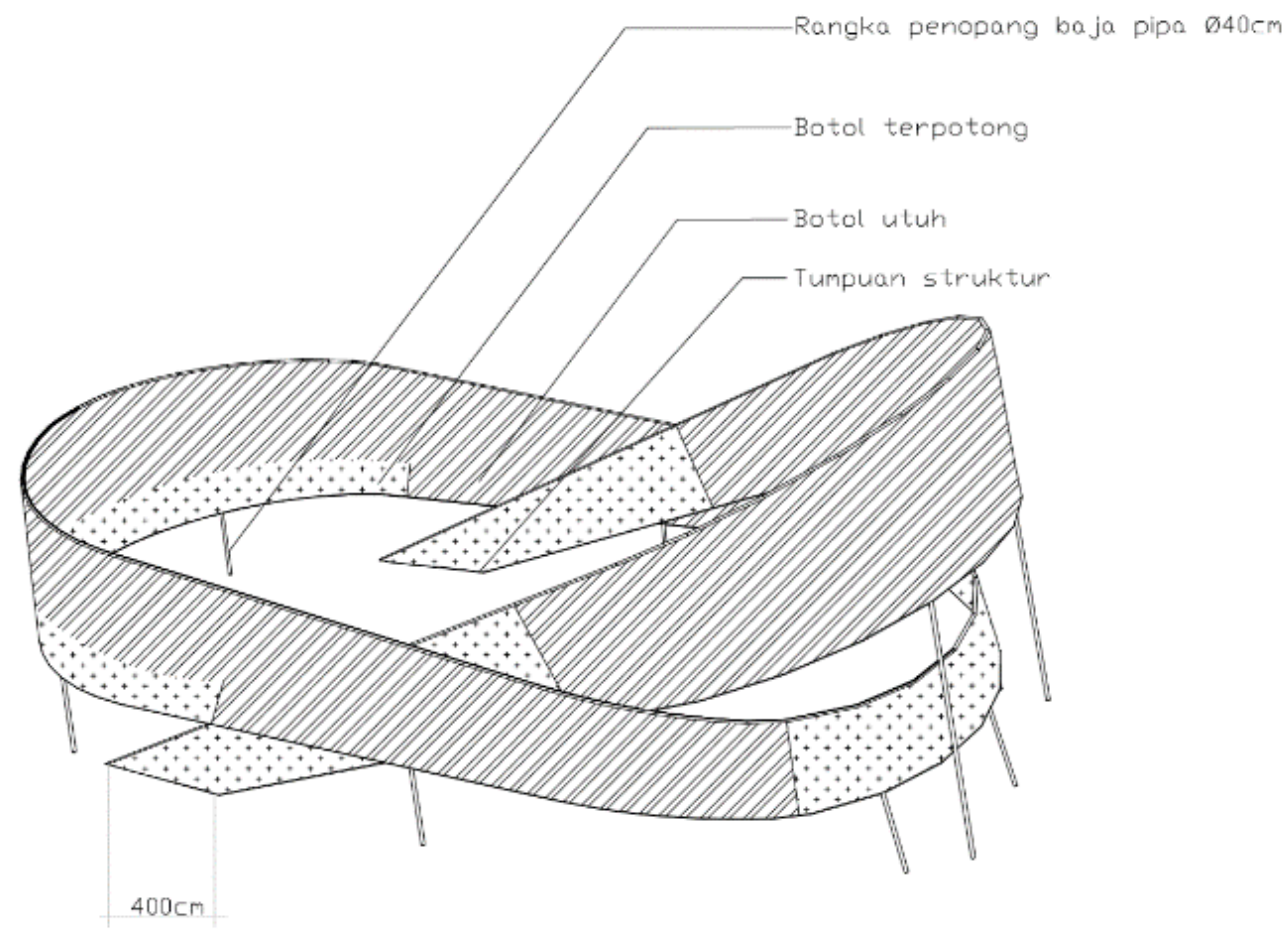

Gambar 7. Bentuk Secondary Skin

Sumber: Penulis, 2020 
Cahaya matahari yang terik diupayakan terblokir oleh second skin yang semi-transparan sehingga ruangan menjadi nyaman. Desain dari Second skin terdiri dari botol-botol plastik yang membentuk sebuah barrier (Gambar 8), Void didalam botol dapat memerangkap panas matahari sehingga yang diteruskan hanyalah cahaya samar-samar seperti gambar dibawah ini.

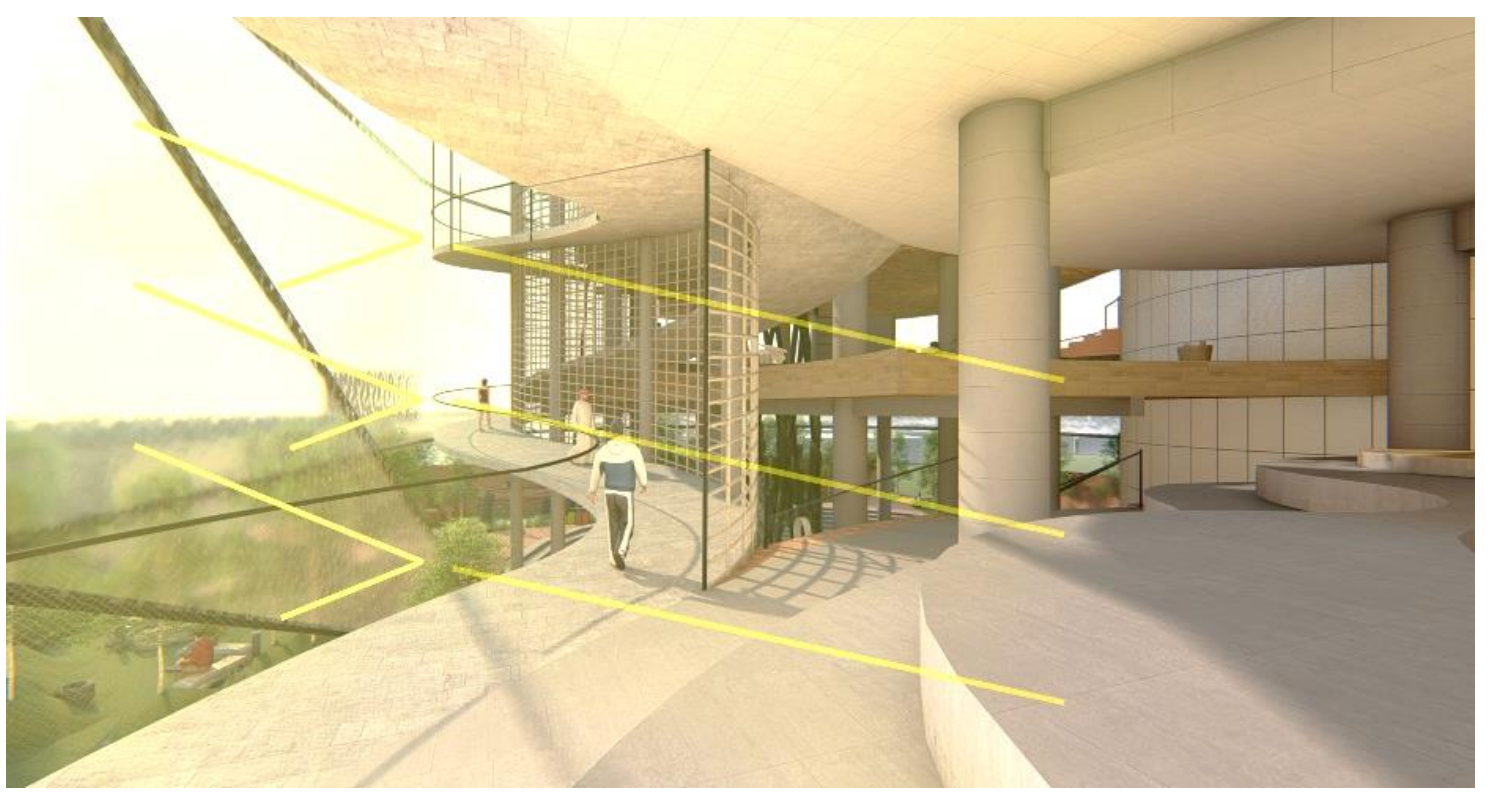

Gambar 8. Secondary Skin Sebagai Pemblokir Panas Matahari

Sumber: Penulis, 2020

Secara material, terdapat empat material utama yang banyak digunakan dalam perencanaan bangunan yaitu papercrete, botol bekas, kayu bekas, dan besi bekas. Selain yang bersifat struktural, hampir semua material menggunakan material daur ulang. Material utama yang paling banyak digunakan adalah papercrete yang menjadi acian dan pelapis di berbagai sisi bangunan, material ini jauh lebih tahan terhadap panas dan memiliki tingkat insulasi yang baik. Kedua, botol plastik $600 \mathrm{ml}$ disusun sedemikian rupa membentuk dinding dan second skin. Ketiga adalah besi bekas, semua railing dan besi-besi yang bersifat non-struktural menggunakan besi bekas yang dicat ulang dan dilapis menggunakan zat anti karat. Material keempat adalah kayu bekas, untuk area kerajinan tangan dan belajar, pelapis yang paling digunakan adalah kayu bekas yang dipotong dan disusun menjadi satu kesatuan. Sebagian besar dari material yang digunakan didalam bangunan merupakan material bekas yang berasal dari sisa-sisa pembangunan, sisa hasil industri dan niaga, sampah rumah tangga, dan lainlainnya yang diolah kembali menjadi material layak pakai (Gambar 9). Penggunaan material bekas ini bertujuan untuk membuktikan secara konkrit bahwa material bekas dapat diolah untuk menjadi benda, atau bahkan bangunan yang indah. Melalui bangunan yang merupakan 'mahakarya' yang terbuat dari gabungan-gabungan sampah ini, masyarakat diajak untuk mengolah sampah yang ada di lingkungan. Selain itu, dalam proses pembangunan dan keberlangsungan aktivitas di proyek ini akan sangat banyak menyerap dan mengolah sampahsampah sisa sehingga secara langsung ataupun tidak langsung kualitas lingkungan akan secara perlahan meningkat, dan berefek pada peningkatan Kesehatan masyarakat secara kualitatif dan menyeluruh. 


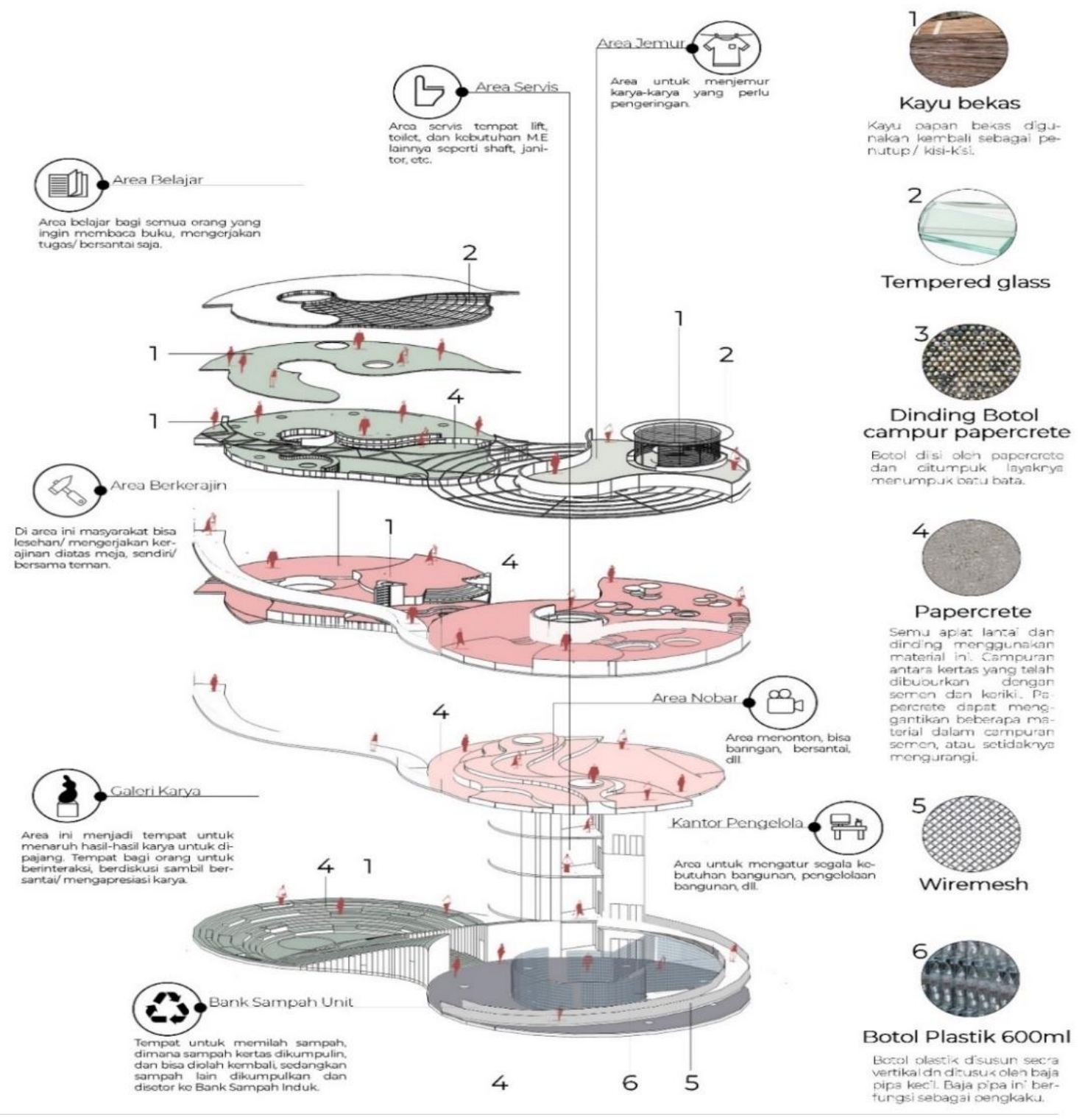

Gambar 9. Exploded Axonometry

Sumber: Penulis, 2020

\section{KESIMPULAN DAN SARAN}

\section{Kesimpulan}

Terdapat dua poin penting yang menjadi kesimpulan pada penelitian ini dan yang menjadikan bangunan ini adalah bangunan yang ideal bagi warga Cengkareng Timur, yaitu:

a. Proyek sebagai fasilitas dan ruang sosial bagi masyarakat yang bersifat informal.

Proyek Third place ini, didesain dengan memperhatikan pendapat dan masukan dari masyarakat sekitar sehingga desain bangunan tidak semata-mata merupakan hasil dari pemikiran sang arsitek namun merupakan akumulatif dari aspirasi-aspirasi masyarakat sekitar. Kedepannya bangunan ini dapat menjadi tujuan bagi masyarakat untuk menikmati waktu luang baik itu untuk belajar, bersosialisasi, berkarya, ataupun untuk bersantai.

b. Dampak dari third place bisa tidak hanya secara sosial, namun dapat mempengaruhi berbagai aspek dari kehidupan masyarakat secara luas. Third place sebagai fasilitas dan wadah sosial selain dapat berdampak secara sosial terhadap masyarakatnya juga dapat turut aktif berdampak pada berbagai aspek kehidupan lainnya. Third place yang sepenuhnya memenuhi kebutuhan masyarakat dapat menjadi tempat yang menyimpan 
memori, sebuah tempat yang mencerminkan penggunanya, dapat berdampak secara ekonomi, budaya, perilaku dan bahkan lingkungan, tergantung dari program dan tujuan daripada third place itu sendiri. Melalui proyek ini masyarakat dapat tidak hanya sekedar bersosialisasi namun melalui program yang ada masyarakat dapat mengaktualiasikan diri, meningkatkan kreativitas, meningkatkan perekonomian, dan secara langsung maupun tidak langsung menjadi lebih peduli terhadap sampah dan lingkungan.

\section{Saran}

Proyek ini masih jauh dari kata sempurna dan masih memiliki berbagai kekurangan yang dikarenakan oleh keterbatasan pengetahuan penulis, oleh karena itu kritik dan saran sangat diharapkan dari pembaca. Berikut adalah beberapa saran dari penulis untuk perkembangan selanjutnya:

a. Secondskin dapat dikembangkan menjadi lebih interaktif atau berbentuk lebih menarik lagi.

b. Material-material lain mungkin masih ada yang bisa disubtitusikan atau lebih diefisienkan lagi penggunaannya.

c. Program-program tambahan yang mungkin dimasukkan lagi.

\section{REFERENSI}

Altman, I. (1975). The Environment and Social Behavior: Privacy, Personal Space, Territory, Crowding. Monterey: Brooks/Cole Publishing Company.

Arsyad, L. (2004). Pengantar Perencanaan Pembangunan. Yogyakarta: Media Widya Mandala. Ayudiana, S. (2019). "Benarkah Kerajinan Kertas Bisa Meredam Stress?". Retrieved Februari 10, 2020, from https://www.antaranews.com/berita/810223/benarkah-kerajinan-kertas-bisameredam-stres.

BPS. (2019). Cengkareng Timur dalam Angka 2019. Jakarta: Badan Pusat Statistik jakarta Barat. Csikszentmihalyi, M. (1990). Flow: The Psychology of Optimal Experience. Pennsylvania: Harper Perennial.

Goble, F. G. (1970). The Third Force: The Psychology of Abraham Maslow. Michigan: Grossman. Halim, D. (2005). Psikologi Arsitektur: Pengantar Kajian Lintas Disiplin. Jakarta: Grasindo. Katyal, N. K. (2002). Architecture as Crime Control. The Yale Law Journal, 111, 1039-1137. Oldenburg, R. (1989). The Great Good Place. Boston: De Capo Press.

Osmond, H. (1957). Function as the Basis of Psychiatric Ward Design. Psychiatric Services, 8 (4), 23-29.

Shah, R. C., \& Kesan, J. (2007). How architecture regulates. Chicago: University of Illinois. Sjarief, R., \& Hidayat, A. (2019). Methodgram: Methodology Grammar. Jakarta: RAW Press. Whyte, W. H. (1980). The Social Life of Small Urban Space. Washington D. C.: Conservation Foundation. 